\title{
Anatomical observation on release of tuber dormancy in water yam (Dioscorea alata L.)
}

\author{
Hironobu Shiwachi ${ }^{\star}$, Shuwan Chen, Ryo Matsumoto, Atusi Sanada and Hidekazu Toyohara
}

Department of International Agricultural Development, Graduate School of Agriculture Science, Tokyo University of Agriculture, 1-1-1, Sakuragaoka, Setagaya, Tokyo, Japan.

Accepted 23 April, 2013

\begin{abstract}
The effects of gibberellin (GA) and a gibberellin inhibitor were investigated on bud growth of two water yam (Dioscorea alata L.) varities. The tubers were harvested after plants senescenced and were subsequently treated with GA and the gibberellin inhibitor uniconazole-P (UP). Tuber dormancy was radically prolonged by GA, but not influenced by UP. The bud germination was observed 90 days after harvesting in both varieties. However, the differentiated shoot meristem was found under microscope observation on top of tuber (corm) at harvesting. It was thought that the shoot meristem development started before harvesting. The observed dormancy period of $\mathbf{9 0}$ days was not actual dormancy period, and the true plant dormancy released before or with plant senescence. GA treatment after plant senescence inhibited the shoot meristem development.
\end{abstract}

Key words: Dioscorea alata, dormancy, gibberellin, shoot meristem development, yams.

\section{INTRODUCTION}

Tuber dormancy of yams (Dioscorea spp.) is an important mechanism for adaptation to their natural environments (Craufurd et al., 2001). Life cycles, the lengths of growth and dormancy of yams are closely adjusted to seasonal changes. On the other hand, restriction to a single cropping season per year and long tuber dormancy are major constraints to flexibility on yam production (Asiedu et al., 1998). A reliable means to induce sprouting in dormant seed tubers of yams is therefore required to enhance flexibility in planting date and harvesting period of the crop.

The mechanism of dormancy in yam tubers is not fully understood although various changes in hormonal composition during the dormant period are known (Craufurd et al., 2001). Three phases of tuber dormancy are proposed in white yam ( $D$. rotundata) (lle et al., 2006). The tuber dormancy of three phases are as below: "phase one: the tuber initiation to the appearance of the tuber germinating meristem"; "phase two: the tuber germinating meristem to initiation of foliar primordium"; and "phase three: the foliar primordium to appearance of the shoot bud on the surface of the tuber" (lle et al., 2006). These dormant phases are endo-dormancy, endoleco-dormancy and eco-dormancy, respectively. Manipulation of dormancy duration in "phase one and two" are important for off-season planting and to produce more than one generation per year.

Endogenous gibberellins (GAs) have been implicated in the tuber dormancy mechanism in water yam $(D$. alata) (Park et al., 2003b). Although gibberellins generally hasten the breaking of dormancy in the seeds and buds of many plant species, the duration of tuber dormancy period of water yam has been prolonged by $\mathrm{GA}_{3}$ and shortened by gibberellin inhibitors (Nnodu and Alozie, 
1992; Girardin et al., 1998; Onjo et al., 1999; Park et al., 2003b; Otoo et al., 2009). Gibberellin inhibitors, uniconazole-P [(E)-(S)-1-(4-chlorophenyl)-4, 4-dimethyl2- $(1 \mathrm{H}-1,2$, 4-triazol-1-yl) pent-1-en-3-ol] applied to tubers shortened the period of dormancy in some varieties of water yam (Shiwachi et al., 2003b).

However, the effect of such plant growth regulators (PRGs) to tuber dormancy with anatomical sprouting process is not understood in water yam. In this study, the influences of gibberellin and uniconazole-P application at the plant senescence period were anatomically described on release or prolonged tuber dormancy in water yam tuber.

\section{MATERIALS AND METHODS}

The experiments were carried out at the Tokyo University of Agriculture (TUA), Tokyo, Japan from April 2009 to April 2010 using two local varieties of water yam. Obukosumbori (introduced from Papua New Guinea) and Okinawa-A (local variety in Japan) were obtained from the germplasm collection at TUA. Seed tubers were prepared by cutting tubers harvested in the previous year into small pieces of around 45 to $50 \mathrm{~g}$ in fresh weight. Seed tubers were sterilized with Benrate (Sumitomo Chemical, Japan) for $5 \mathrm{~min}$ and their cut surfaces were covered with caustic lime on 4 April, 2009. They were allowed to sprouted in plastic pots $(15 \mathrm{~cm}$ in diameter and $12.5 \mathrm{~cm}$ in depth) filled with vermiculite and incubated at about $25^{\circ} \mathrm{C}$ under dark conditions covered by box in a green house. After 30 days incubation, sprouted seedlings were transplanted to the field of TUA at a spacing of $100 \times 50 \mathrm{~cm}$ on 3 May. Basic fertilizer (100 kgha ${ }^{-1}$ per each chemical ingredients consisting of N, P and K) was applied following the chinese yam ( $D$. opposita) cultivating guideline issued by the Kanagawa Prefecture (Kanagawa Prefecture Government, 2006). Growing plants were staked with 2 $\mathrm{m}$ high poles. Tubers were harvested after plant senescence on 3 December, and used for the following experiments.

\section{$\mathrm{GA}_{3}$ and uniconazole-P tuber treatment}

Whole tubers weighing 300 to $500 \mathrm{~g}$ with $75( \pm 1.5) \%$ of moisture content were washed at harvest, air-dried for $24 \mathrm{~h}$, and then soaked in $10 \mathrm{mg} \mathrm{L}^{-1}$ of $\mathrm{GA}_{3}(\mathrm{GA})$ and $5 \mathrm{mg} \mathrm{L}^{-1}$ of uniconazole-P (UP) for 24 h. The UP solution was prepared by diluting Sumiseven ${ }^{\circledR}$ P (UP content of $0.025 \%$ produced by Agros Co. Ltd., Japan). The concentrations of these solutions were referred by Onjo et al. (1999) and Shiwachi et al. (2003b). Twenty five tubers were randomly selected from both varieties. Treated tubers were kept in a dark room at $20^{\circ} \mathrm{C}, 70 \%$ relative humidity.

Tubers from both varieties were treated with water for identical periods as controls. Whole 10 tubers were randomly selected from 25 tubers as use bud germination observation. The observation of bud germination was recorded at 30 day intervals during the experiment. A tuber was declared germinated when an emerged bud reached $3 \mathrm{~mm}$ in length. The period of sprouting was recorded as the time from harvest to when sprouting of $80 \%$ of the tubers.

\section{Microscopic observation of bud germination}

The other 15 tubers were used for microscopic observation of bud development. Three tubers were transversally cut into $1 \mathrm{~cm}^{3}$ cubes with tuber skins for microscope observations at 30,60,90 and
120 days after harvesting. Only at harvesting, 9 tubers were observed for bud or shoot apical meristem on tubers. After being washed, they were soaked in the FAA solution (formalin: acetic acid: ethanol = 5: 5: 90) for fixation for $24 \mathrm{~h}$. Fixed samples were dehydrated with the t-butanol series and embedded in paraffin. Embedded samples were cut into 10 to $20 \mu \mathrm{m}$ thick sections by using a microtome (Erma Optical Works, Japan). Prepared paraffin sections were stained with hematoxylin to be observed under a transmission optical microscope (Olympus 50 BM, Japan).

\section{RESULTS AND DISCUSSION}

The tuber dormancy period was 90 days after treatment (DAT) in cv. Obukosumbori and Okinwa-A in both the control and UP treatments (Table 1). The tuber-sprouting rate of both varieties in the control and UP treatments was 80 and $100 \%$ at 90 DAT. The number of buds was 0.8-1.0 and 1.0-1.1 per one tuber in Obukosumbori and Okinwa-A, respectively. On the other hand, dormancy in GA treated tubers was prolonged in both varieties compared to control. Sprouting rate of the GA treated tuber in both varieties was $20 \%$ by the 150 DAT when control tubers had $100 \%$ germinated. This result was same as previous reports in water yam varieties (Onjo et al., 1999; Park et al., 2003b). The dormancy period of the UP treated tubers did not differ from control. Park et al. (2003b) reported that UP treated tubers had shortened tuber dormancy, but the UP did not influence either water yam varieties in this experiment. UP treatments shortened tuber dormancy in Dioscorea spp., but the effectiveness of UP varied among varieties (Shiwachi et al. 2003b). UP did not contribute to shortened dormancy in the varieties used in their experiment.

When water yam tubers were harvested with head of tuber (corm), bigger buds were found on or around corm. Generally, these buds were dormant for $3-4$ months, and elongated after the end of tuber dormancy in water yam (Park et al., 2003a). When the corm of tuber had damaged at the harvesting, the new bud developed on the part of tuber head. In this study, the differentiated shoot meristem was found under microscope observation on corm area on both varieties at harvesting (Table 2). The rate of bud or shoot meristem development under microscope observation in Obukosumbori and Okinwa-A was 33.3 and $66.6 \%$, respectively. Figure 1 shows the shoot meristem on Okinwa-A at harvesting, and the results show that the some tubers were non-dormant. At tuber harvest, the dormancy phase in Okinawa-A was determined to be either endo or eco-dormancy. The visible bud germination in tubers was observed 90 DAT in both varieties of control and UP treatment (Table 1). At 90 DAT, the shoot meristem was developed at the shoot (foliar) primordium (Figure 2). The observed dormancy period of 90 days was not actual dormancy period, and the true plant dormancy released before tuber harvesting. At 90 DAT on GA treated tubers of Okinawa-A, the layer of meristematic cells had not developed on the 
Table 1. Rate (\%) and number of bud sprouted on tuber of $D$. alata varieties by gibberellin and Uniconazol-P treatments $(\mathrm{n}=10)$.

\begin{tabular}{|c|c|c|c|c|c|c|}
\hline \multirow{2}{*}{ Treatment } & \multirow{2}{*}{ Variety } & \multirow{2}{*}{ Check items } & \multicolumn{4}{|c|}{ Days after treatment } \\
\hline & & & 60 & 90 & 120 & 150 \\
\hline \multirow[t]{4}{*}{ Control } & Obukosumbori & Germinated bud (\%) & 0 & 80.0 & 100.0 & 100.0 \\
\hline & & No. of bud (s.e.) & 0 & $0.8(0.4)$ & $2.0(0.4)$ & $2.2(0.4)$ \\
\hline & Okinawa-A & Germinated bud (\%) & 20.0 & 100.0 & 100.0 & 100.0 \\
\hline & & No. of bud (s.e.) & $0.3(0.6)$ & $1.0(0.0)$ & $1.2(0.4)$ & $1.3(0.6)$ \\
\hline \multirow[t]{4}{*}{$\mathrm{GA} 10 \mathrm{mgL}^{-1}$} & Obukosumbori & Germinated bud (\%) & 0 & 0 & 0 & 20.0 \\
\hline & & No. of bud (s.e.) & 0 & 0 & 0 & $0.2(0.4)$ \\
\hline & Okinawa-A & Germinated bud (\%) & 0 & 0 & 20.0 & 20.0 \\
\hline & & No. of bud (s.e.) & 0 & 0 & $0.3(0.6)$ & $0.6(1.3)$ \\
\hline Uniconazol - P & Obukosumbori & Germinated bud (\%) & 0 & 80.0 & 100.0 & 100.0 \\
\hline \multirow[t]{3}{*}{$5 \mathrm{mgL}^{-1}$} & & No. of bud (s.e.) & 0 & $1.0(0.6)$ & $1.5(0.7)$ & $1.9(0.5)$ \\
\hline & Okinawa-A & Germinated bud (\%) & 40.0 & 100.0 & 100.0 & 100.0 \\
\hline & & No. of bud (s.e.) & $0.5(0.7)$ & $1.1(0.3)$ & $1.2(0.4)$ & $1.4(0.5)$ \\
\hline
\end{tabular}

Table 2. Rate (\%) of developed bud or shoot meristem on tuber of $D$. alata varieties at harvesting $(n=9)$.

\begin{tabular}{lc}
\hline Variety & Number of developed bud or shoot apical meristem (s.e.) \\
\hline Obukosumbori & $33.3(0.47)$ \\
Okinawa-A & $66.6(0.47)$ \\
\hline
\end{tabular}

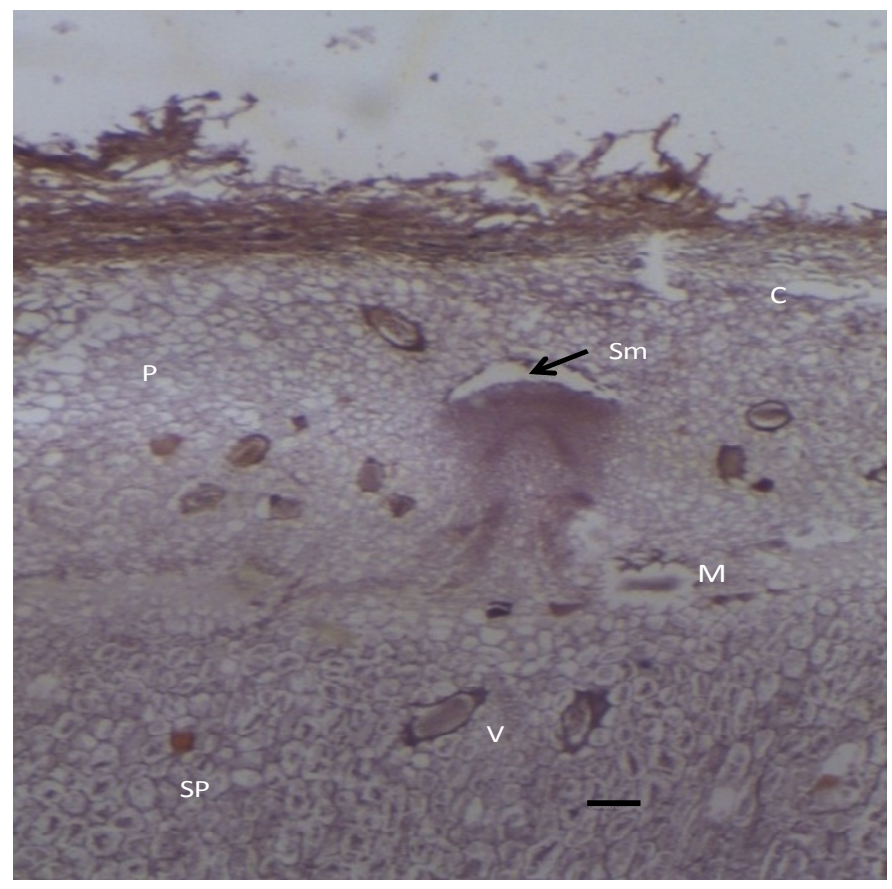

Figure 1. Transverse section of head area (com) of tuber at harvesting in cv. Okinawa-A (Control). Scale bar $=100 \mu \mathrm{m}, \mathrm{Sm}$ : Shoot meristem, C: cork layer, M: layer of meristematic cell, P: parenchyma cell, SP: storage parenchyma cell with stored starch. 


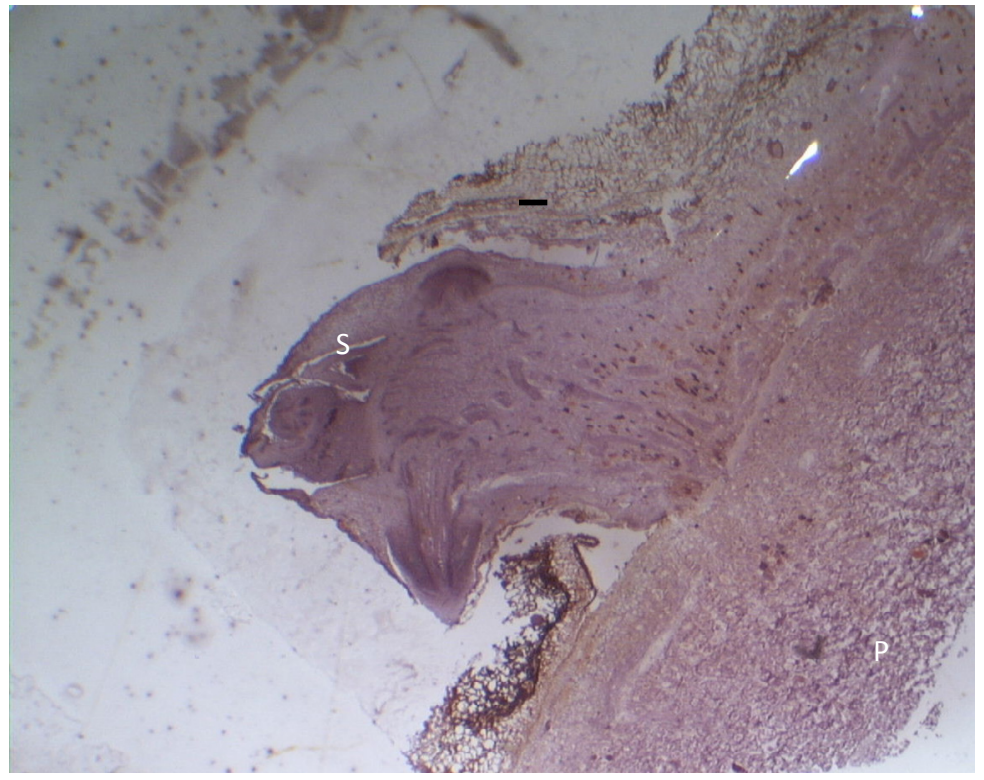

Figure 2. Transverse section in head area of tuber on 90 days after harvest of cv. Okinawa-A (Control). Scale bar $=100 \mu \mathrm{m}$, S: developed shoot, P: parenchyma cell.

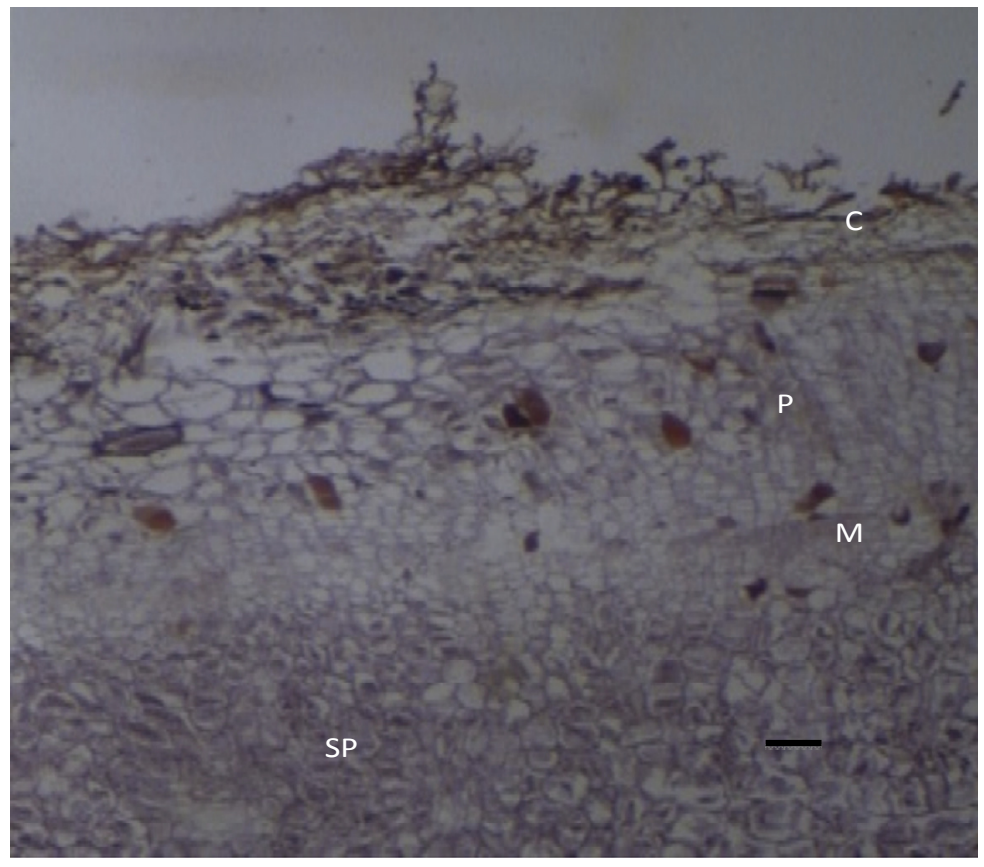

Figure 3. Transverse section of skin on middle part of tuber treated by GA $10 \mathrm{mgL}^{-1}$ at 90 days after harvesting of cv. Okinawa-A. Scale bar $=100$ $\mu \mathrm{m}, \mathrm{C}$ : cork layer, M: layer of meristematic cell, P: parenchyma cell, SP: storage parenchyma cell with stored starch.

middle part of tuber skin (Figure 3). GA treated tubers had inhibited development of the shoot meristematic cells. On GA treated tubers of Obukosumbori, the visible bud germination was $20 \%$ at 150 days after treatment (Table 1). Most bud differentiation was primary stage of shoot development at this period (Figure 4). GA 


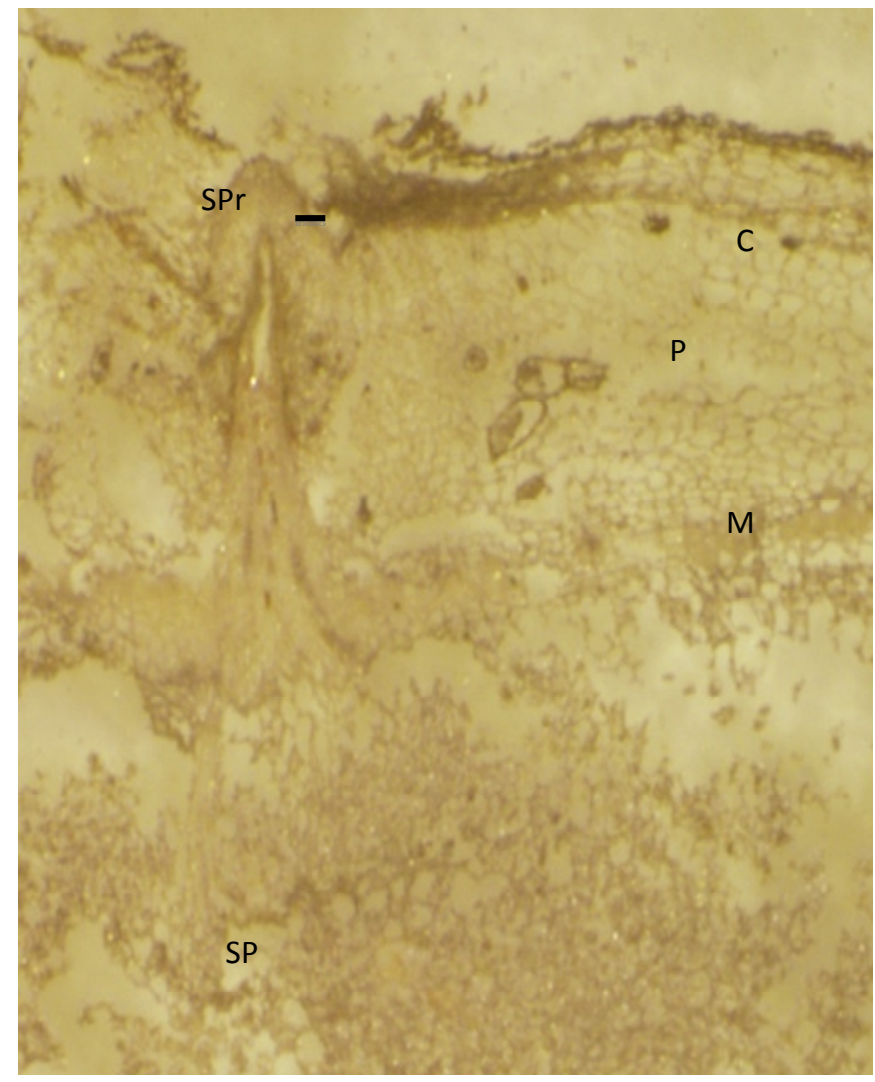

Figure 4. Transverse section of head area on tuber treated by GA $10 \mathrm{mgL}^{-1}$ at 150 days after harvesting of cv. Obukosumbori. Scale bar $=100 \mu \mathrm{m}, \mathrm{C}$ : cork layer, $\mathrm{M}$ : layer of meristematic cell, P: parenchyma cell, SP: storage parenchyma cell with stored starch, SPr: shoot primordial.

treatment at the plant senescence stage prolonged the endo-/eco-dormancy period in both water yam varieties. From those observations, we identified that the release of tuber dormancy started prior to plant senescence, and the shoot meristematic cell development inhibited by GA in water yam.

\section{REFERENCES}

Asiedu R, Ng SYC, Bai KV, Ekanayaka IJ, Wanyera NMW (1998). Genetic Improvement, In: Orkwor, GC, Asiedu R and Ekanayaka IJ (eds.), Food yam, Advances in Research, IITA and NRCRI, Nigeria. pp. 63-104.

Craufurd PQ, Summerfield RJ, Asiedu R, Vara Prasad PV (2001). Dormancy in Yams. Exp. Agric. 37:75-109.

Girardin O, Nindjin C, Farah Z, Escher F, Stamp P, Otokoré D (1998). Use of gibberellic acid to prolong dormancy and reduce losses during traditional storage of yam. J. Sci. Food Agric. 77:172-178.

lle El, Craufurd PQ, Battey NH and Asiedu R (2006). Phases of Dormancy in Yam Tubers (Dioscorea rotundata). Ann. Bot. 97:497504

Kanagawa Prefectural Government (2006). Standard fertilizing for each crop in Kanagawa Prefecture. http://www.pref.kanagawa.jp/osirase/nogyosinko/sehi19/h19-1-1. pdf (accessed 2009-04-20).

Nnodu EC, Alozie SO (1992). Using gibberellic acid to control sprouting of yam tubers. Trop. Agric. 69:329-332.

Onjo M, Okamoto S, Hayashi M (1999). Effects of gibberellins on growth, enlargement and dormancy of tubers in Dioscorea alata L. Jpn. J. Trop. Agric. 43:65-70.

Otoo E, Shiwachi H, Onjo M (2009). Preliminary investigations into the effect of uniconazole-P and prohexadione calcium on sprouting and shoot length of Dioscorea rotundata, $D$. alata and $D$. cayenensis in Ghana. J. Food Agric. Environ. 7(2):481-486.

Park B, Onjo M, Tominaga S, Shiwachi H, Hayashi M (2003a). Relationship between the dormancy and its release and external factors in tubers of water yam (Dioscorea alata L.). Jpn. J. Trop. Agric. 47:42-50.

Park B, Onjo M, Tominaga S, Shiwachi H, Hayashi M (2003b). Relationship between the release of dormancy and the activity of endogenous gibberellins in the tubers of water yam (Dioscorea alata L.). Jpn. J. Trop. Agric. 47:51-57.

Shiwachi H, Ayankanmi T, Asiedu R (2003b). Influence of exogenous gibberellin inhibitors on tuber germination in yam (Dioscorea spp.) Trop. Sci. 43:147-151. 